\title{
Cutaneous Ulcers in an Untreated HIV Patient
}

\author{
Xavier Bosch-Amate ${ }^{1}$, Xavier Fustà-Novell ${ }^{1}$, Daniel Morgado-Carrasco ${ }^{1}$
}

1 Department of Dermatology, Hospital Clínic de Barcelona, Universitat de Barcelona, Spain

Key words: cutaneous ulcers, syphilis, malignant syphilis, men who have sex with men

Citation: Bosch-Amate X, Fustà-Novell X, Morgado-Carrasco D. Cutaneous ulcers in an untreated HIV patient. Dermatol Pract Concept. 2021;11(2):e2021007. DOI: https://doi.org/10.5826/dpc.1102a07

Accepted: August 5, 2020; Published: March 8, 2021

Copyright: (02021 Bosch-Amate et al. This is an open-access article distributed under the terms of the Creative Commons Attribution License BY-NC-4.0, which permits unrestricted noncommercial use, distribution, and reproduction in any medium, provided the original author and source are credited.

Funding: None.

Competing interests: The authors have no conflicts of interest to disclose.

Authorship: All authors have contributed significantly to this publication.

Corresponding author: Daniel Morgado-Carrasco, MD, Dermatology Department, Hospital Clínic, University of Barcelona, Spain. Email: morgadodaniel8@gmail.com

\section{Case Presentation}

A 22-year-old man presented with a 6-month history of asthenia, anorexia, severe weight loss of $20 \mathrm{~kg}$, low-grade fever, and cutaneous lesions that had occurred within 1 month. More importantly, this patient presented with untreated HIV infection. Physical examination revealed a few erythematous and ulcerated plaques (some with necrotic crusts) on his trunk and extremities (Figure 1) and absence of lesions on mucous membranes, palms and soles. Blood tests showed $284 \mathrm{CD} 4 / \mu \mathrm{L}$ and HIV viral load 243,000 copies/mL. Nontreponemal tests showed elevated VDRL titers (1/32). Lumbar puncture ruled out neurosyphilis. With a diagnosis of malignant syphilis, benzathine penicillin 2.4 MU was administered intramuscularly with complete resolution of symptoms.

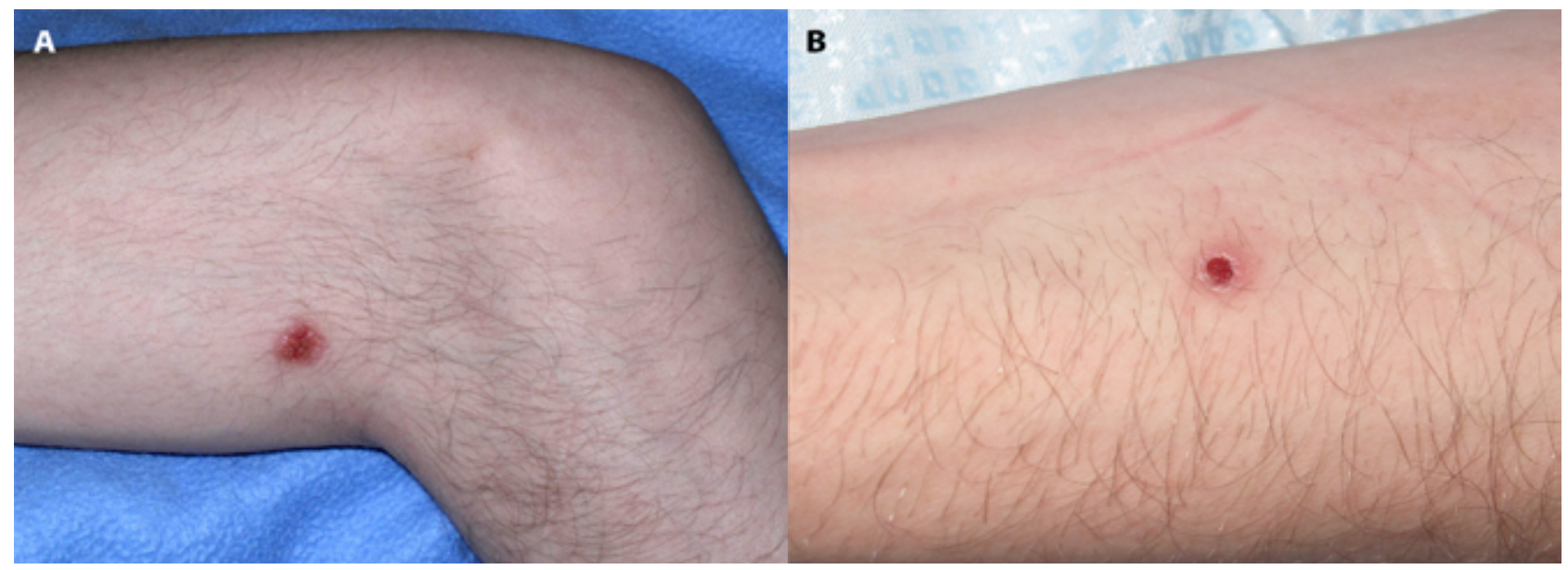

Figure 1. (A, B) Malignant syphilis. Erythematous and ulcerated plaques with well-demarcated borders on the left arm. 


\section{Teaching Point}

Syphilis has a broad spectrum of mucocutaneous manifestations. Malignant syphilis is a rare form of secondary syphilis, associated in most cases with HIV infection, that could present with a few cutaneous lesions. In our case histopathology was not done; however, it usually shows the presence of a dense inflammatory infiltrate, sometimes with a lichenoid pattern, with lymphocytes, plasma cells, and occasional presence of granulomas. Early detection of the coexistence of secondary syphilis and HIV infection is essential for correct management and the avoidance of serious complications [1,2].

\section{References}

1. Tucker JD, Shah S, Jarell AD, Tsai KY, Zembowicz A, Kroshinsky D. Lues maligna in early HIV infection case report and review of the literature. Sex Transm Dis. 2009;36(8):512-514. DOI: $10.1097 /$ OLQ.0b013e3181a2a946. PMID 19455078.

2. Fustà-Novell X, Morgado-Carrasco D, Barreiro-Capurro A, et al; Miembros del Grupo de Trabajo de Infecciones de Transmisón Sexual del Hospital Clínic de Barcelona. Syphilis maligna: a presentation to bear in mind. Actas Dermosifiliogr. 2019;110(3):232-237. DOI: 10.1016/j.ad.2018.02.024. PMID 30098705. 